\title{
Intravenous high-dose ascorbic acid reduces the expression of inflammatory markers in peripheral mononuclear cells of subjects with metabolic syndrome
}

\author{
Nina Mikirova*\# and Ruth C Scimeca ${ }^{*}$ \\ Riordan Clinic, 3100 North Hillside, Wichita, KS, USA
}

\begin{abstract}
Chronic hyper nutrition is associated with marked oxidative stress and inflammation. Recent studies show that intravenously administered ascorbic acid (IVC), which has been used to treat conditions including fatigue, infection, and cancer, can have an effect on gene expression and epigenetic phenomena. Hence, we analyzed the effect of IVC on mRNA levels of several genes involved in inflammation and stress response. The gene expression modulation in peripheral blood mononuclear cells (PBMCs) from 20 overweight or obese subjects was determined. Participants were infused twice with 15 grams ascorbic acid (AA), with a one-day interval between treatments. The expression profile of several genes related to the inflammation and anti-oxidative enzymes was quantified by real time reverse transcription polymerase chain reaction (qRT-PCR). Total AA and dehydroascorbic acid (DHA) were measured in plasma before and after each treatment. Lipid profile and C-reactive protein (CRP) were measured by Bio-Center Laboratory of the Riordan Clinic by standard procedures. We confirmed that, in our subjects expression of mRNA levels of Interleukin 4 (IL-4) and Interleukin 6 (IL-6) correlated with inflammation, as indicated by CRP levels. Moreover, mRNA expression of these genes tended to correlate with body mass index (BMI) and high blood lipid levels. Treatments by IVC resulted in significant increase of blood AA and DHA concentrations. Analysis of mRNA levels on PBMC before and after IVC showed down-regulation of genes coding for Interleukin 8 (IL-8) and up-regulation of Nuclear factor erythroid-derived 2 (NRf2), IL-4, Interleukin 10 (IL-10), Tumor necrosis factor alpha (TNF- $\alpha$ ), and Interferon gamma (IFN- $\gamma$ ). IVC treatment yielded regulation of immunological genes in PBMCs, suggesting potential benefits in regulating inflammation and redox potential.
\end{abstract}

\section{Introduction}

Obesity can be accompanied by chronic low grade inflammation, oxidative stress, and a cluster of symptoms including hypertension, dyslipidemia, impaired glucose tolerance, and insulin resistance [1-6]. These symptoms, in turn, are associated with respiratory and cardiovascular disease, type two diabetes, fatty liver, visceral adiposis, early aging, cancer, and increased mortality [1,2,7-9]. In an effort to understand the development of adiposity, the interplay between inflammation, oxidative stress, and obesity has been studied extensively $[1,2]$.

The chronic low-grade inflammation that accompanies abdominal obesity is of particular interest, since expression of inflammation markers, such as CRP and pro-inflammatory cytokines, correlate with symptoms such as hypertension and insulin resistance [2,5,8,9-17]. Pro-inflammatory cytokines such TNF- $\alpha$ and IL-6 are overexpressed in obese subjects, as is nuclear factor kappa-light-chain-enhancer of activated $\mathrm{B}$ cells $(\mathrm{NF}-\mathrm{\kappa} \mathrm{B})$, the transcription factor that controls many genes associated with inflammation. Moreover, subjects with adiposity show reduced serum levels of the anti-inflammatory cytokine IL-10 [11-13]. The production of adipokines also changes in patients with adiposity. Adipose tissue cells produce both pro-inflammatory (leptin, plasminogen activation inhibitor 1 , TNF- $\alpha$, angiotensinogen, IL- 6 and anti-inflammatory (adiponectin) cytokines, but the balance tilts toward production of the pro-inflammatory cytokines in overweight and obese subjects [2].

Changes in cellular gene expression have also been detected in overweight and obese patients. In obese individuals, adipose tissue cells and PBMCs exhibit an increase in gene expression of proinflammatory cytokines $[2,10-12,14-16,18]$. In addition, mononuclear cells in these subjects are characterized by increased expression and activities of transcription factors NF- $\mathrm{B}$, as well as decreased levels of the inhibitor of kappa light polypeptide gene enhancer in B cells, kinase beta (IKKB-B) $[11,14]$. Diet induced weight loss in patients with adiposity has been shown to correct gene expression abnormalities related to pro-inflammatory cytokine production and to reduce NF- $\kappa B$ activation in PBMCs.

The inflammation observed in obese subjects may be triggered by oxidative stress $[19,20]$. Excess consumption of glucose and fatty acids leads to tricarboxylic acid (TCA) cycle overload and increased Acetyl-CoA production [2]. Excess Acetyl-CoA stimulates production of reactive oxygen species (ROS) from the electron transport chain reactions in mitochondria, leading to hydrogen peroxide buildup [2]. This oxidative stress induces changes in the expression of genes associated with cancer progression [21,22]. Oxidation may also influence the length of telomeres, nucleotide sequences at the end of chromosomes that play a role in cancer and are inversely related

Correspondence to: Nina Mikirova, Riordan Clinic, 3100 North Hillside, Wichita, KS, USA, E-mail: nmikirova@riordanclinic.org

\#These authors contributed equally to this work

Key words: obesity, metabolic syndrome, high dose intravenous vitamin $C$, inflammation, gene expression, pro-inflammatory, anti-inflammatory cytokines

Received: April 12, 2016; Accepted: April 26, 2016; Published: April 30, 2016 
Mikirova N (2016) Intravenous high-dose ascorbic acid reduces the expression of inflammatory markers in peripheral mononuclear cells of subjects with metabolic syndrome

to insulin resistance [22,23]. Finally, oxidative stress modulates transcription factors, including NF- $\mathrm{BB}$ and activation protein one (AP-1), involved in differentiation, proliferation, and apoptosis [18]. In contrast, diets high in antioxidant rich foods such as olive oil, fruits, and vegetables have been shown to lower mRNA levels of inflammatory cytokines in PBMCs [24,25].

Vitamin C (AA) is a water soluble antioxidant that may also modulate gene expression [26-28]. When AA is infused intravenously at doses of 10 grams or higher, it can reach millimolar concentrations in the blood. At these concentrations, it shows cytotoxicity against some types of cancer cells [29-31] and inhibits the expression of NF$\kappa \mathrm{B}$ genes [32-33]. It also suppresses specificity protein transcription factors (Sp1, 2, 3, and 4) and modulates tumor protein 53 (p53) [34,35]. Several studies have also shown the positive effects of high dose IVC in cancer patients as an adjunct therapy or by itself $[36,37]$.

The experiments in the present manuscript are designed to determine if, and how, IVC might affect the mRNA expression levels of PBMCs in overweight and obese subjects. We have chosen to analyze mRNA levels on PBMC since they play key roles in the inflammatory process and are easy to obtain [14,18]. PBMCs have been shown increased expression of pro-inflammatory cytokine production in obese subjects [18], correlating with visceral fat amounts and inflammation in these subjects [14-16,38,39]. Also, PBMCs from overweight individuals have shown increased secretion of pro-inflammatory cytokines, including TNF- $\alpha$, IFN- $\gamma$, and interleukin two (IL-2), along with decreased secretion of the anti-inflammatory cytokine IL-10 [24,40]. Therefore, we measured gene expression of several cytokines and other proteins in PBMC from overweight subjects before and after treatments with IVC.

\section{Materials and methods}

\section{Recruitment of subjects}

Twenty subjects ( 15 women and 5 men, ages 30 to 71 ) were recruited for a short-term (one week) study, in order to assess the effect of IVC on gene expression in PBMCs. Subjects were recruited among the employees of the Riordan Clinic and provided written informed consent to participate in the study. The research was in compliance of the declaration of Helsinki and approved by the Institutional Review Board of Riordan Clinic.

All participants were in good health as determined by a medical history and clinical laboratory tests. Subjects fulfilled the following criteria:

\section{1) No history of chronic disease}

2) No antibiotic or supplemental vitamin $C$ use for two weeks before the beginning of the study

3) Nonsmoking

4) No drugs or nonsteroidal inflammatory drugs two weeks before and during the study.

Subjects with type 1 diabetes mellitus, autoimmune diseases, malignant diseases, and infectious diseases were excluded from the study. Participants maintained their usual habits including physical, sleeping habits and diet during the study. All subjects were overweight as defined by a body mass index (BMI) above 25 .

After enrollment, participants received two $15 \mathrm{~g}$ IVC treatments, with a one day interval between treatments, following the procedure outlined in the Riordan IVC protocol (www.riordanclinic.org/ protocol). Blood samples were drawn immediately before and after each IVC treatment.

\section{Isolation of PBMC}

Whole blood was collected by venipuncture into heparinized tubes. For PBMC collection, blood was diluted 1:1 with phosphate buffered saline (PBS), layered on top of Ficoll-Paque Plus (Amersham Biosciences), and centrifuged at $400 \mathrm{~g}$ for 30 minutes at $4^{\circ} \mathrm{C}$. PBMC were then removed from the plasma-Ficoll interface by pipette and rinsed twice with PBS.

\section{RNA extraction and $q R T-P C R$}

PBMCs were removed from PBS and $1 \mathrm{ml}$ of TriReagent (SigmaAldrich, Hercules CA) was added for RNA extraction following manufacturer's instructions. Total RNA quality and quantity was evaluated using the Nanodrop ND-2000 (Thermo Scientific, Pittsburg PA) and subsequently converted to cDNA using the iScript RT supermix in the CFX96 Real-Time PCR Detection System (Bio-Rad, Hercules, CA, USA). cDNA was than quantified using the Nanodrop ND-2000 and a total of $250 \mathrm{ng}$ were used to analyze gene-specific oligonucleotide primers (Table 1) with the SsoAdv Universal SYBR GREEN Kit. A dissociation curve was run at the end of the reaction to ensure that only one amplicon was formed and that the amplicons denatured consistently in the same temperature range for every sample. The cDNA levels were normalized against housekeeping gene Ribosomal protein 13 (RPS13).

\section{Plasma ascorbic acid and dehydroascorbic acid levels}

Initial levels of reduced and oxidized AA were measured in the morning between two and three hours after breakfast for each subject. A two $\mathrm{mL}$ aliquot of heparinized whole blood was centrifuged at 1000 $\mathrm{g}$ for 10 minutes and plasma was harvested. Plasma was then diluted 1:5 with methanol/water for AA and DHA determinations. The AA and DHA assays were conducted as described previously [41-42] using a commercially available kit (“Ascorbic Assay Kit”, Cayman

Table 1: Oligonucleotide primers and PCR conditions for inflammatory response genes.

\begin{tabular}{|c|c|c|c|}
\hline Genbank Access. \# & Symbol and Description & Primers & qPCR* \\
\hline NM_000576.2 & $\begin{array}{l}\text { IL1 } \beta \\
\text { Interleukin } 1 \text { beta }\end{array}$ & $\begin{array}{l}\text { HsIL1BF: ggagaatgacctgagcacct } \\
\text { HsIL1BR: ggaggtggagagctttcagt }\end{array}$ & $56^{\circ} \mathrm{C}$ \\
\hline NM_000586.3 & $\begin{array}{l}\text { IL2 } \\
\text { Interleukin } 2\end{array}$ & $\begin{array}{l}\text { HsIL2F: ggatgcaactcctgtcttgc } \\
\text { HsIL2R: tgtgagcatcctggtgagtt }\end{array}$ & $57^{\circ} \mathrm{C}$ \\
\hline NM_172348.2 & $\begin{array}{l}\text { IL4 } \\
\text { Interleukin } 4\end{array}$ & $\begin{array}{l}\text { HsIL4F: gcagttctacagccaccatg } \\
\text { HsIL4R: actctggttggcttcettca }\end{array}$ & $58^{\circ} \mathrm{C}$ \\
\hline NM_000600.3 & $\begin{array}{l}\text { IL6 } \\
\text { Interlukin } 6\end{array}$ & $\begin{array}{l}\text { HsIL6F: agtcctgatccagttcctgc } \\
\text { HsIL6R: aagctgcgcagaatgagatg }\end{array}$ & $56^{\circ} \mathrm{C}$ \\
\hline NM_000584.3 & $\begin{array}{l}\text { CXCL8 } \\
\text { Interleukin } 8\end{array}$ & $\begin{array}{l}\text { HsIL8F: cagtttgccaaggagtgct } \\
\text { HsIL8R: acttctccacaaccctctgc }\end{array}$ & $58^{\circ} \mathrm{C}$ \\
\hline NM_000572.2 & $\begin{array}{l}\text { IL10 } \\
\text { Interleukin } 10\end{array}$ & $\begin{array}{l}\text { HsIL10F: gccaagccttgtctgagatg } \\
\text { HsIL10R: aagaaatcgatgacagcgec }\end{array}$ & $58^{\circ} \mathrm{C}$ \\
\hline NM_000594.3 & $\begin{array}{l}\text { TNF } \\
\text { Tumor Necrosis Factor }\end{array}$ & $\begin{array}{l}\text { HsTNFF: gtcaacctcctctctgccat } \\
\text { HsTNFR: ccaaagtagacctgcccaga }\end{array}$ & $57^{\circ} \mathrm{C}$ \\
\hline NM_000619.2 & $\begin{array}{l}\text { IFNG } \\
\text { Interferon gamma }\end{array}$ & $\begin{array}{l}\text { HsIFNGF: gcagagccaaattgtctcc } \\
\text { HsIFNGR: tgctttgcgttggacattca }\end{array}$ & $57^{\circ} \mathrm{C}$ \\
\hline NM_001165412 & $\begin{array}{l}\text { NFkB } \\
\text { Nuclear factor kappa B }\end{array}$ & $\begin{array}{l}\text { NFkBF: gcacgacaacatctcattgg } \\
\text { NFkBR: tcccaagagtcatccaggtc }\end{array}$ & $58^{\circ} \mathrm{C}$ \\
\hline NM_001313904.1 & $\begin{array}{l}\text { NRf2 } \\
\text { Nuclear factor erythroid } 2\end{array}$ & $\begin{array}{l}\text { NRf2F gcgacggaaagagtatgagc } \\
\text { NRf2R gttggcagatccactggttt }\end{array}$ & $57^{\circ} \mathrm{C}$ \\
\hline NM_001017.2 & $\begin{array}{l}\text { RSP13 } \\
\text { Ribosomal protein } 13\end{array}$ & $\begin{array}{l}\text { RPS13F: cgaaagcatcttgagaggaaca } \\
\text { RPS13R: tcgagccaaacggtgaatc }\end{array}$ & $57^{\circ} \mathrm{C}$ \\
\hline
\end{tabular}


Mikirova N (2016) Intravenous high-dose ascorbic acid reduces the expression of inflammatory markers in peripheral mononuclear cells of subjects with metabolic syndrome

Chemical Co.). Briefly, ascorbic acid is oxidized to dehydroascorbic acid, which then reacts with o-phenylenediamine (ophenylenediamine dihydrochloride (OPDA), Sigma Aldrich) to form the condensation product. This allows to measure total ascorbate (AA+DHA). Addition of buffer instead of oxidizing reagent (Tempol; CAS No: 2226-96-2, Sigma-Aldrich) results in the measurements of DHA. Concentrations of AA were calculated by subtraction of DHA from total ascorbate. The fluorescence emission of the resulting product was measured by Fluorolog -3 by fluorescence at excitation $340-350 \mathrm{~nm}$ and emission $420-430 \mathrm{~nm}$.

\section{Clinical parameters}

Lipid profile and CRP in blood serum (collected by venipuncture and centrifugation) were measured by Bio-Center Laboratory of the Riordan Clinic by standard procedure.

\section{Statistical analysis}

The analysis and comparisons of mRNA expression levels were carried out using the Kaleidagraph (Synergy Software, Reading PA, USA) and Systat Software ( San Jose, CA, USA) statistical software. Data are presented as mean \pm SD. Pre and post treatment comparison was performed using paired t-tests and ANOVA. Differences in mean values were considered significant at the level of $95 \%(\mathrm{p}<0.05)$. Outliers in gene expression data were removed based on the interquartile range test. The $2^{-\Delta \Delta C t}$ method was used to calculate differences in gene expression.

\section{Results}

\section{Initial Parameters}

Basic characteristics of the subjects at the beginning of the study are presented in the Table 2. No adverse effects were observed after IVC infusions. Based on comparison of mean values to normal ranges, subjects in general were obese (three quarters of the subjects had mean BMI values above 30) with elevated cholesterol levels and abnormally high lipid-to-HDL ratios. This occurs because while HDL levels tend to fall within the normal range, the levels of other lipids (cholesterol, triglycerides, VLDL, and LDL) tend toward higher levels, with significant percentages of patients showing above-normal values. Blood pressure levels were, on average, normal, but the mean CRP level for these subjects was substantially above normal, with seventy percent

Table 2: Initial parameter values for study subjects.

\begin{tabular}{|c|c|c|c|}
\hline Parameter & Mean \pm SD & Normal Range & Abnormal Cases \\
\hline Age (yrs.) & $45 \pm 14$ & & \\
\hline Systolic BP (mm Hg) & $124 \pm 15$ & & \\
\hline Diastolic BP (mm Hg) & $77 \pm 11$ & & \\
\hline Body Mass (kg) & $96 \pm 26$ & & \\
\hline BMI & $34.2 \pm 9.4$ & 18.5 to 25.0 & $74 \%$ Obese (26\% Overweight) \\
\hline Cholesterol (mg/dL) & $200 \pm 44$ & 100 to $200 \mathrm{mg} / \mathrm{dL}$ & 47\% Above Normal Range \\
\hline Triglycerides $(\mathrm{mg} / \mathrm{dL})$ & $144 \pm 70$ & 35 to $150 \mathrm{mg} / \mathrm{dL}$ & $33 \%$ Above Normal Range \\
\hline VLDL (mg/dL) & $28.7 \pm 14.0$ & 5 to $30 \mathrm{mg} / \mathrm{dL}$ & $33 \%$ Above Normal Range \\
\hline $\mathrm{HDL}(\mathrm{mg} / \mathrm{dL})$ & $50.7 \pm 16.5$ & 29 to $80 \mathrm{mg} / \mathrm{dL}$ & 7\% Below Normal Range \\
\hline LDL (mg/dL) & $121 \pm 42$ & 50 to $100 \mathrm{mg} / \mathrm{dL}$ & $80 \%$ Above Normal Range \\
\hline Cholesterol/HDL Ratio & $4.2 \pm 1.2$ & 0 to 4.4 & 47\% Above Normal Range \\
\hline LDL/HDL Ratio & $2.6 \pm 1.0$ & 0 to 3.2 & $40 \%$ Above Normal Range \\
\hline Glucose (mg/dL) & $101 \pm 25$ & 65 to $99 \mathrm{mg} / \mathrm{dL}$ & $33 \%$ Above Normal Range \\
\hline Plasma Ascorbate $(\mu \mathrm{M})$ & $50 \pm 37$ & 34 to $114 \mu \mathrm{M}$ & $15 \%$ Below Normal Range \\
\hline C-Reactive Protein $(\mathrm{mg} / \mathrm{L})$ & $6.0 \pm 5.2$ & 0 to $1.9 \mathrm{mg} / \mathrm{L}$ & $71 \%$ Above Normal Range \\
\hline
\end{tabular}

of the subjects having CRP levels outside the normal range, suggesting that inflammation was an issue in many of the subjects.

\section{Plasma ascorbate and dehydroascorbate}

Prior to intravenous ascorbate treatments, the average plasma ascorbic acid concentration was $50 \pm 37 \mu \mathrm{M}$, and most values fell within the normal range (Table 2). Intravenous infusions increased these AA levels by roughly two orders of magnitude, with mean value one hour post infusion reaching $6.4 \pm 3.1 \mathrm{mM}$ (or $6400 \pm 3100 \mu \mathrm{M}$ ). We observed a linear relationship between the post-IVC plasma AA concentrations and the dose given, normalized to body mass $(r=0.60, p<0.01$; data not shown). The mean dehydroascorbic acid concentration in plasma before treatment was $55 \pm 30 \mu \mathrm{M}$, and the initial mean AA:DHA ratio was $1.1 \pm 0.8$.

After IVC, the mean DHA concentration increased to $2.0 \pm 1.6$ $\mathrm{mM}$ and the AA:DHA ratios increased dramatically. This is shown in Figures 1(a-c), where distributions of AA, DHA, and AA:DHA before and after IVC infusion are shown.

The difference in $\mathrm{X}$-axis scale between Figures 1a (before IVC) and $1 \mathrm{~b}$ (after IVC) show the two order of magnitude increase due to infusion. According to our data, the infusion increase in AA is more than three times as great as that of DHA, but is also more variable, leading to the wide range in AA:DHA values observed post infusion (Figure 1c). The AA:DHA ratios, in fact, show a strong ( $\mathrm{r}=0.77)$ inverse correlation with CRP concentration. Since CRP is an inflammation marker, and inflammation is thought to be accompanied by oxidative stress, the data in Figure 2 are consistent with the idea that redox conditions accompanying inflammation may increase the rate of AA oxidation to DHA.

\section{mRNA gene expression levels before IVC infusions}

We examined potential correlations between mRNA levels in PBMC and CRP, BMI, and various lipid profile parameters. Based on linear regression, mRNA expression of IL- 6 and IL-4 increase with increasing CRP levels (linear regression, $r=0.55, \mathrm{p}<0.02$ and $\mathrm{r}=0.52$, $\mathrm{p}<0.02$ respectively) while mRNA levels of IFN $-\gamma$ slightly decreased with increasing CRP levels $(\mathrm{r}=0.26, \mathrm{p}<0.17)$. The results for IL-4 are illustrated in Figure 3. This suggests that mRNA expression levels of some inflammatory cytokines were higher in patients who showed higher levels of inflammation via CRP concentration.

To examine the relationship between PBMC mRNA levels and $\mathrm{BMI}$, we divided subjects into quartiles based on BMI:

\section{Q1: below 28.0;}

Q2: 28.0 to 39.7 ;

\section{Q3: 39.7 to 41.6 ;}

\section{Q4: above 41.6.}

Figure 4 shows the ratio of mRNA levels for subjects in the fourth quartile (Q4) to those in the first quartile (Q1). According to our data, the increases in BMI are associated with a three-fold increase in the expression of IL-6, along with less dramatic increases in TNF- $\alpha$, IL-1, IL-8, and CRP. Meanwhile, IL-10, IL-2, and IFN- $\gamma$ were downregulated in the heaviest subjects relative to the least heavy.

Figure 5, shows the significant correlation between PBMC IL-6 expression and BMI. In general, mRNA expression in PBMC showed a trend with increased BMI: direct association between BMI and 

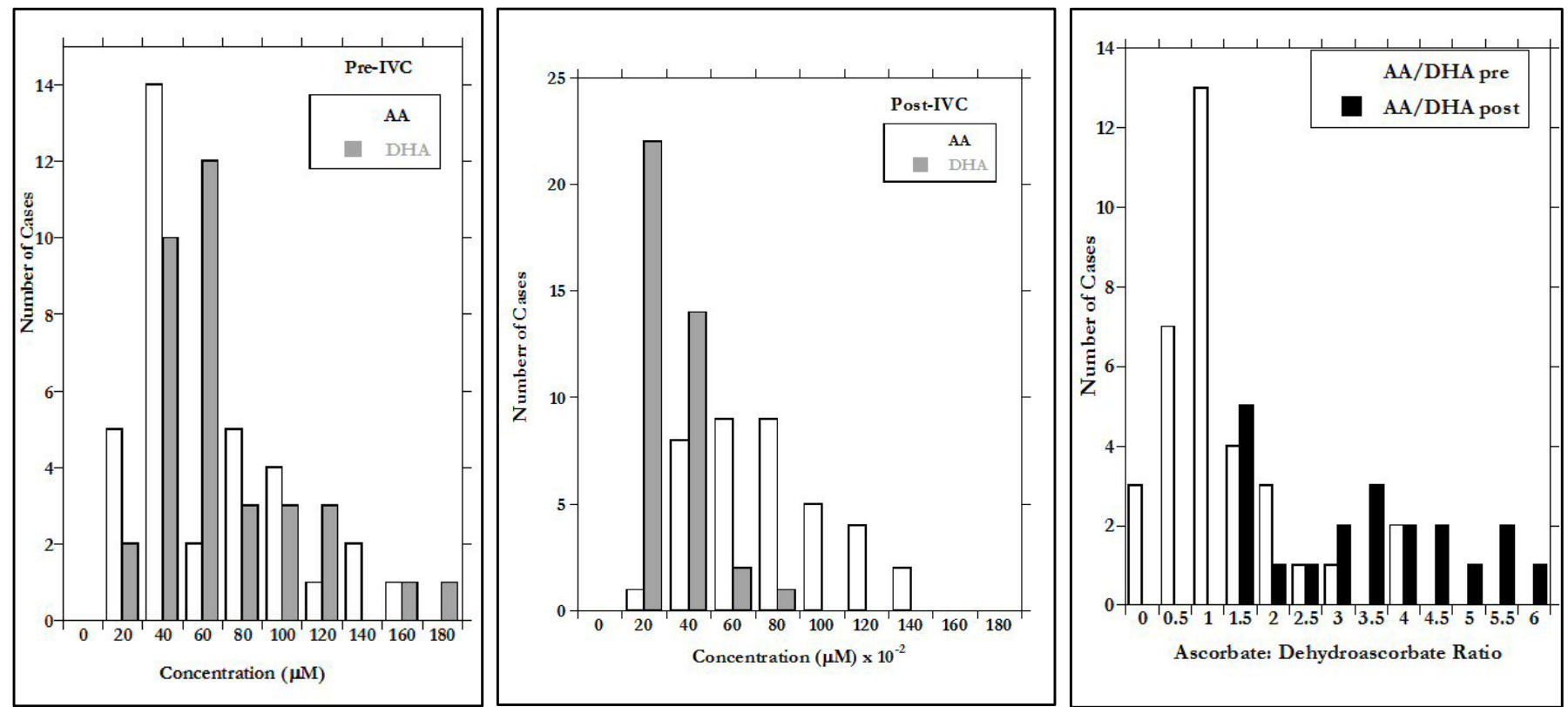

Figure 1. a) AA and DHA concentrations prior to IVC; b) AA and DHA concentrations after 15 grams IVC infusions; c) Distributions of the ratio AA to DHA concentrations before and after 15 grams IVC infusions.

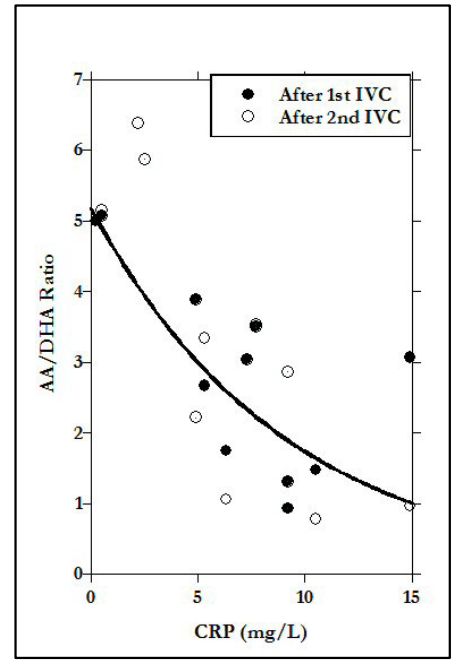

Figure 2. Ratio of AA to DHA in plasma of overweight subjects after IVC. Data fit: $y=5.3 e^{-0.2 x} \quad(\mathrm{r}=0.77)$.

pro-inflammatory markers IL-8, IL-6, IFN- $\gamma$ and inverse association with IL-10, IL-2, but for most of markers the correlations were not statistically significant.

In addition, we examined potential correlations between PBMC mRNA levels of selected genes and lipid profile parameters. Correlations were analyzed between the target gene expressions and cholesterol, triglycerides, VLDL, HDL cholesterol, LDL, cholesterol to HDL ratio and LDL to HDL ratios. TNF- $\alpha$ expression correlated directly with triglycerides $(\mathrm{r}=0.4, \mathrm{p}<0.1)$, VLDL $(\mathrm{r}=0.4, \mathrm{p}<0.1)$ and cholesterol/HDL ratio $(\mathrm{r}=0.41, \mathrm{p}<0.09)$, while correlating inversely with HDL $(\mathrm{R}=-0.44, \mathrm{p}<0.07)$. Other correlations we found included: IL-8 and cholesterol $(\mathrm{R}=0.4, \mathrm{p}<0.1)$, IL-10 and VLDL $(\mathrm{R}=-0.37, \mathrm{p}<0.14)$, IL- 6 and cholesterol $(\mathrm{R}=0.69, \mathrm{p}<0.01)$, IL- 6 and LDL $(\mathrm{r}=0.6, \mathrm{p}<0.01)$; IL- 4 and cholesterol/HDL $(\mathrm{R}=0.45, \mathrm{p}<0.06)$, and IL- 4 and LDL/HDL ratio $(\mathrm{R}=0.43, \mathrm{p}<0.08)$. These results confirm the idea that conditions

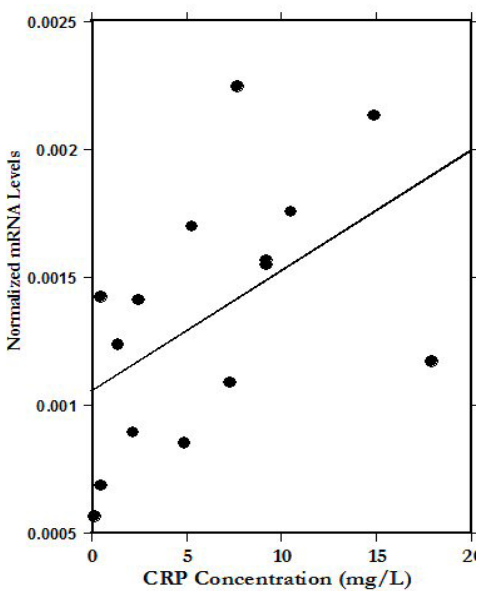

Figure 3. Correlation between CRP concentrations and mRNA IL-4 gene expression levels before IVC treatments $(\mathrm{r}=0.52)$.

associated with adiposity, such as dyslipemia, are accompanied by changes in PBMC gene expression favoring inflammation.

\section{Effect of IVC on PBMC gene expression}

Table 3 shows PBMC mRNA expression levels of various cytokines during the time course of the study. In general, IL-1, IL-2, IL-6 and NF$\kappa \mathrm{B}$ showed no discernable, statistically significant, systematic changes during the time frame of the study. For the cytokines IL-4, IL-10, NRf2 and TNF- $\alpha$ gene expression levels remained constant during the first IVC, but then rose after the second IVC infusion (Table 3).

The most dramatic and statistically significant changes during the study occurred with IL- 8 and IFN- $\gamma$ expressions. Data for all changed genes are shown in Figure 6A and 6B.

For IL-8, a pro-inflammatory cytokine, gene expression in PBMCs 


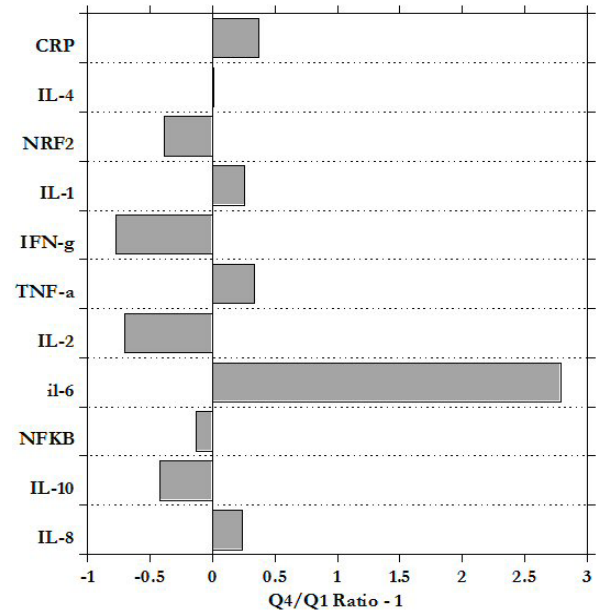

Figure 4. Ratio of mRNA expression for heaviest quartile to that for the lightest quartile, minus one (negative values show downregulation in Q4 subjects relative to Q1).

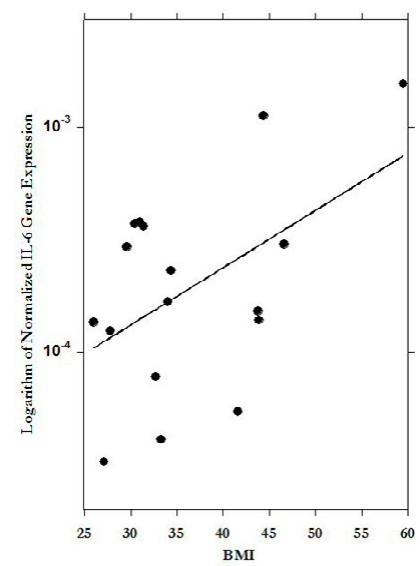

Figure 5. Correlation between body mass index (BMI) and IL-6 mRNA levels in PBMCs $(\mathrm{r}=0.78)$.

decreased during the time course of the study, with values before IVC infusions (Pre) being significantly higher than those after IVC infusions (Post). This is especially interesting since IL- 8 is up-regulated by oxidative stress; adding the antioxidant ascorbate may reduce IL-8 mRNA levels by reducing oxidative stress. In the case of NRf2, a molecule associated with cellular response to oxidative stress, and one that is below normal in obese subjects in general, gene expression after second IVC infusion was significantly higher than that seen before IVC. This is also a potentially positive development, as NRf2 signaling is involved in the upregulation of enzymes that mediate the detoxification of reactive metabolites and ROS.

\section{Discussion}

The subjects in this study tended toward obesity, and showed typical symptoms of adiposity, including elevated cholesterol and lipid levels (other than HDL), high blood glucose concentrations, and abnormally high levels of the inflammation marker CRP. Conditions associated with adiposity, in turn were accompanied by changes in PBMC gene expression favoring inflammation. For example, mRNA levels of IL- 6 and IL-4 correlated with BMI and with CRP concentration, as did TNF- $\alpha$, IL-1, IL-8, to a lesser degree. Moreover, mRNA levels of TNF- $\gamma$ and IL-8 correlated with cholesterol levels in these subjects. This is consistent with observations in the literature that inflammatory cytokine levels correlate with obesity [17]. High CRP levels also correlated with reduced AA:DHA ratios, consistent with reports in the literature associating inflammation in obese subjects with oxidative stress.

The investigation of the association mRNA levels of proinflammatory and anti-inflammatory markers in PBMCs before treatment with BMI sorted by quartiles (Q3 vs. Q1) demonstrated upregulated mRNA levels of IL-6 (ratio 3.8), IL-1, IL-8, TNF- $\alpha$ and serum CRP and reduced mRNA levels of IL-10, IL-2, INF- $\gamma$ and NRf2.

Since IVC is used extensively in our clinic, and, as it was shown in our studies, high dose intravenous ascorbic acid can act to reduce inflammation [44-45], we were interested in learning how IVC might affect inflammation in subjects with adiposity. The treatments of participants by IVC resulted in significant increase of AA, DHA concentrations and ratio AA to DHA in blood. This ratio was decreased with increased levels of inflammation in participants, which may be explained by increased level of oxidative stress in subjects with metabolic syndrome.

Our study was too short-term to examine how vitamin C might benefit health overall for these subjects and more females than males were included, but we did learn that the infusions can have some effect on PBMC gene expression. For instance, mRNA levels of the inflammatory cytokine IL- 8 were reduced significantly during the study, while expression of NRf2, which plays a role in counteracting oxidative stress, was increased. On the other hand, mRNA levels of TNF- $\alpha$, IL-4 and IL-10 remained constant until the second IVC infusion, at which point they increased. TNF- $\alpha$ has distinct effects on adipose tissue, including stimulation of lipolysis, suppression of lipogenesis, induction of adipocyte dedifferentiation, and impairment of pre-adipocyte differentiation in vitro. TNF- $\alpha$ may also induce apoptosis in human adipose cells [43]. Thus, the increase in TNF- $\alpha$ expression may be beneficial in modifying adipose tissue mass.

We did not see an effect of IVC infusion on mRNA levels of NF$\kappa \mathrm{B}$. This is somewhat surprising since multiple treatments with IVC have been shown to reduce levels of inflammatory cytokines in patients with cancer and rheumatoid arthritis [44-45]. These studies measured concentration, rather than gene expression, and used treatments carried out of over a longer duration.

mRNA levels of the pro-inflammatory cytokines (IL-1, IL-6) were not significantly affected by IVC, but this may simply be a case of not having enough replicate data points, or may be due to the short duration of the study (two infusion, one week). The treatment caused upregulation of anti-inflammatory markers such as IL-10 and IL-4. We also found up-regulation of mRNA expression of INF- $\gamma$ as the result of the treatments $(\mathrm{p}<0.002)$.

The possibility that IVC increases mRNA levels of NRf2 (there was not a change from the beginning of the study to the end of the first injection, but levels post-IVC infusion were significantly higher than levels immediately prior to infusion for the second IVC) is of interest due to the link between inflammation and oxidative stress. Aerobic organisms are thought to have acquired this gene through evolution in order to protect them against ROS damage [46-49]. NRf2 expression is induced by oxidative stress, and is central to efficient detoxification of reactive metabolites and ROS [50,51]. Over two-hundred gene 
Mikirova N (2016) Intravenous high-dose ascorbic acid reduces the expression of inflammatory markers in peripheral mononuclear cells of subjects with metabolic syndrome

Table 3: Average normalized gene expression levels for each of the four time points (pre- and post- IVC infusion 1 and pre-and post- IVC infusion 2) along with p-values are given obtained from paired t-tests.

\begin{tabular}{|c|c|c|c|c|c|c|c|c|c|}
\hline & & I Pre & I Post & II Pre & II Post & p-value (pre1/post1) & p-value (pre2/post2) & p-value (pre1/post2) & Effect of IVC \\
\hline \multirow[t]{2}{*}{ IL-1 } & Mean & 0.0078 & 0.0080 & 0.0151 & 0.0085 & 0.36 & 0.08 & 0.14 & No Effect \\
\hline & SD & 0.0076 & 0.0071 & 0.0157 & 0.0064 & & & & \\
\hline \multirow[t]{2}{*}{ IL-2 } & Mean & 0.0011 & 0.0017 & 0.0008 & 0.0011 & 0.12 & 0.22 & 0.47 & No Effect \\
\hline & SD & 0.0013 & 0.0018 & 0.0006 & 0.0017 & & & & \\
\hline \multirow[t]{2}{*}{ IL-4 } & Mean & 0.0016 & 0.0014 & 0.0016 & 0.0019 & 0.13 & 0.04 & 0.08 & $\begin{array}{c}\text { Increase at final } \\
\text { IVC }\end{array}$ \\
\hline & SD & 0.0006 & 0.0009 & 0.0008 & 0.0010 & & & & \\
\hline \multirow[t]{2}{*}{ IL-6 } & Mean & 0.0002 & 0.0002 & 0.0002 & 0.0002 & 0.44 & 0.06 & 0.16 & No Effect \\
\hline & SD & 0.0001 & 0.0001 & 0.0001 & 0.0001 & & & & \\
\hline \multirow[t]{2}{*}{ IL-8 } & Mean & 0.0660 & 0.0318 & 0.0410 & 0.0236 & 0.001 & 0.05 & 0.002 & Decrease \\
\hline & SD & 0.0468 & 0.0297 & 0.0370 & 0.0183 & & & & \\
\hline \multirow[t]{2}{*}{ IL-10 } & Mean & 0.0002 & 0.0002 & 0.0004 & 0.0003 & 0.058 & 0.03 & 0.03 & Increase \\
\hline & SD & 0.0002 & 0.0001 & 0.0006 & 0.0003 & & & & \\
\hline \multirow[t]{2}{*}{ IFN- $\gamma$} & Mean & 0.0010 & 0.0014 & 0.0012 & 0.0024 & 0.004 & 0.001 & 0.002 & Increase \\
\hline & SD & 0.0007 & 0.0012 & 0.0012 & 0.0023 & & & & \\
\hline \multirow[t]{2}{*}{ TNF- $\alpha$} & Mean & 0.0018 & 0.0021 & 0.0015 & 0.0040 & 0.30 & 0.02 & 0.03 & Increase \\
\hline & SD & 0.0018 & 0.0017 & 0.0018 & 0.0044 & & & & \\
\hline \multirow[t]{2}{*}{$\mathrm{NF}-\kappa \mathrm{B}$} & Mean & 0.0022 & 0.0028 & 0.0024 & 0.0022 & 0.08 & 0.48 & 0.43 & No Effect \\
\hline & SD & 0.0019 & 0.0026 & 0.0032 & 0.0028 & & & & \\
\hline \multirow[t]{2}{*}{ NRf2 } & Mean & 0.0094 & 0.0106 & 0.0045 & 0.0097 & 0.22 & 0.003 & 0.42 & $\begin{array}{l}\text { Increase at final } \\
\text { IVC }\end{array}$ \\
\hline & SD & 0.0074 & 0.0094 & 0.0032 & 0.0065 & & & & \\
\hline
\end{tabular}

6 a

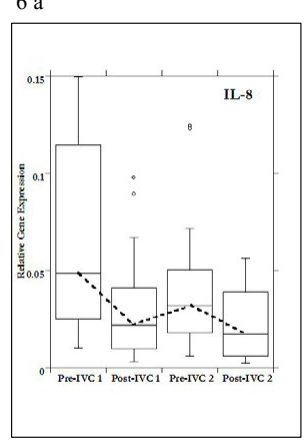

$6 \mathrm{~b}$

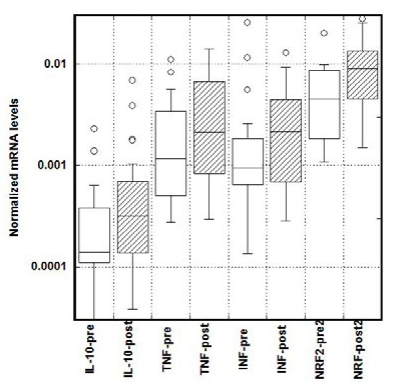

Figure 6. a) Gene expression levels of IL- 8 in PBMCs before (pre) and after (post) two injections; b) Gene expressions of IL-10, TNF- $\alpha$, IFN- $\gamma$ pre and post IVCs and NRf2 -after second IVC.

products are thought to be under the transcriptional control of NRf2, including enzymes responsible for the production of antioxidants and reducing equivalents $[47,52]$. The main classes of NRF2-regulated genes include anti-oxidative enzymes like $\mathrm{NAD}(\mathrm{P}) \mathrm{H}$ :Quinone oxidoreductase (NQO1), epoxide hydrolase, aldehyde dehydrogenase, aldo-keto reductase, catalase, heme oxygenase 1 (HO-1), and enzymes involved in glutathione homeostasis, including glutathione reductases, peroxiredoxin, thioredoxin and thioredoxin reductases and glutathione peroxidase [50,53]. Moreover, NRf2 activation leads to an increased cellular energetics and redox potential [52,53]. Declines in NRf2 levels with ageing promotes oxidative damage, and age related NRf2 inhibition is observed in Parkinson's, Alzheimer's, and Huntington's diseases as well as atherosclerosis [49-56].

The activation of NRf2 by high dose vitamin C treatment can induce the protection against age-related degenerative diseases and cancer. Further studies of the effects of high does vitamin C on NRf2 gene expression would offer the potential to develop treatment to promote longevity, healthy ageing and lower cancer incidence.

In summary, our pilot study demonstrated that high dose vitamin C (IVC 15g) has potential effects in alleviating inflammatory status and improving defense status of PBMCs in subjects with metabolic syndrome.

The limitations of the study are the small size of the analyzed population; participants were not separated by sex and the higher number of females than males included in our research study. Further research in this area and clinical studies of the efficacy of intravenous high dose vitamin $\mathrm{C}$ in the treatment of patients with metabolic syndrome are warranted.

\section{References}

1. Bonomini F, Rodella LF, Rezzani R (2015) Metabolic syndrome, aging and involvement of oxidative stress. Aging Dis 6: 109-120. [Crossref]

2. Muñoz A, Costa M (2013) Nutritionally mediated oxidative stress and inflammation. Oxid Med Cell Longev 2013: 610950. [Crossref]

3. Montero D, Walther G, Stehouwer CD, Houben AJ, Beckman JA, et al. (2014) Effect of antioxidant vitamin supplementation on endothelial function in type 2 diabetes mellitus: a systematic review and meta-analysis of randomized controlled trials. Obes Rev 15: 107-116. [Crossref]

4. Medzhitov R (2008) Origin and physiological roles of inflammation. Nature 454: 428435. [Crossref]

5. Hajer GR, van Haeften TW, Visseren FL (2008) Adipose tissue dysfunction in obesity, diabetes, and vascular diseases. Eur Heart J 29: 2959-2971. [Crossref]

6. Zulet MA, Puchau B, Navarro C, Martí A, Martínez JA (2007) [Inflammatory biomarkers: the link between obesity and associated pathologies]. Nutr Hosp 22: 511527. [Crossref]

7. Boura-Halfon S, Zick Y (2009) Phosphorylation of IRS proteins, insulin action, and insulin resistance. Am J Physiol Endocrinol Metab 296: E581-591. [Crossref]

8. Hotamisligil GS, Shargill NS, Spiegelman BM (1993) Adipose expression of tumo necrosis factor-alpha: direct role in obesity-linked insulin resistance. Science 259: 8791. [Crossref]

9. Van Gaal LF, Mertens IL, De Block CE (2006) Mechanisms linking obesity with cardiovascular disease. Nature 444: 875-880. [Crossref]

10. Bastard JP, Jardel C, Bruckert E, Blondy P, Capeau J, et al. (2000) Elevated levels of 
Mikirova N (2016) Intravenous high-dose ascorbic acid reduces the expression of inflammatory markers in peripheral mononuclear cells of subjects with metabolic syndrome

interleukin 6 are reduced in serum and subcutaneous adipose tissue of obese women after weight loss. J Clin Endocrinol Metab 85: 3338-3342. [Crossref]

11. Satoh-Asahara N, Shimatsu A, Sasaki Y, Nakaoka H, Himeno A, et al. (2012) Highly purified eicosapentaenoic acid increases interleukin-10 levels of peripheral blood monocytes in obese patients with dyslipidemia. Diabetes Care 35: 2631-2639. [Crossref]

12. Esposito K, Pontillo A, Giugliano F, Giugliano G, Marfella R, et al. (2003) Association of low interleukin-10 levels with the metabolic syndrome in obese women. $J$ Clin Endocrinol Metab 88: 1055-1058. [Crossref]

13. Carvalho GQ, Pereira PF, Serrano HM, do Carmo Castro Franceschini S, Oliveira de Paula S, et al. (2010) Peripheral expression of inflammatory markers in overweight female adolescents and eutrophic female adolescents with a high percentage of body fat. Appl Physiol Nutr Metab 35: 464-470. [Crossref]

14. Ghanim H, Aljada A, Hofmeyer D, Syed T, Mohanty P, et al. (2004) Circulating mononuclear cells in the obese are in a proinflammatory state. Circulation 110: 1564 1571. [Crossref]

15. Catalan V, Catala V, Gomez-Ambrosi J, Rodriguez A, Ramirez B, et al. (2015). Peripheral mononuclear blood cells contribute to the obesity associated inflammatory state independently of glycemic status: involvement of the novel pro-inflammatory adipokines chemerin, chitinase-3-like protein, lipocalin-2 and osteopontin. Genes Nutr 10: 11. [Crossref]

16. Weisberg SP, McCann D, Desai M, Rosenbaum M, Leibel RL, et al. (2003) Obesity is associated with macrophage accumulation in adipose tissue. $J$ Clin Invest 112: 17961808. [Crossref]

17. Lucas R, Parikh SJ, Sridhar S, Guo DH, Bhagatwala J, et al. (2013) Cytokine profiling of young overweight and obese female African American adults with prediabetes. Cytokine 64: 310-315. [Crossref]

18. Ghanim H, Aljada A, Hofmeyer D, Syed T, Mohanty P, et al. (2004) Circulating mononuclear cells in the obese are in a proinflammatory state. Circulation 110: 15641571. [Crossref]

19. Ceriello A, Motz E (2004) Is oxidative stress the pathogenic mechanism underlying insulin resistance, diabetes, and cardiovascular disease? The common soil hypothesis revisited. Arterio Thromb Vascular Bio 24: 816-823. [Crossref]

20. Wright E Jr, Scism-Bacon JL, Glass LC (2006) Oxidative stress in type 2 diabetes: the role of fasting and postprandial glycaemia. Int J Clin Pract 60: 308-314. [Crossref]

21. Chervona Y, Costa M (2012) Histone modifications and cancer: biomarkers of prognosis? Am J Cancer Res 2: 589-597. [Crossref]

22. Kurdistani SK (2011) Histone modifications in cancer biology and prognosis. Prog Drug Res 67: 91-106. [Crossref]

23. Demissie S, Levy D, Benjamin EJ, Cupples LA, Gardner JP, et al. (2006) Insulin resistance, oxidative stress, hypertension, and leukocyte telomere length in men from the Framingham Heart Study. Aging Cell 5: 325-330. [Crossref]

24. de Mello VD, Kolehmainen M, Schwab U, Mager U, Laaksonen DE, et al. (2008) Effect of weight loss on cytokine messenger RNA expression in peripheral blood mononuclear cells of obese subjects with the metabolic syndrome. Metabolism 57: 192-199. [Crossref]

25. de Mello VD, Kolehmanien M, Schwab U, Pulkkinen L, Uusitupa M (2012) Gene expression of peripheral blood mononuclear cells as a tool in dietary intervention studies: What do we know so far? Mol Nutr Food Res 56: 1160-1172. [Crossref]

26. Chojkier M, Houglum K, Solis-Herruzo J, Brenner DA (1989) Stimulation of collagen gene expression by ascorbic acid in cultured human fibroblasts. A role for lipid peroxidation? J Biol Chem 264: 16957-16962. [Crossref]

27. Lyons BL, Schwarz RI (1984) Ascorbate stimulation of PAT cells causes an increase in transcription rates and a decrease in degradation rates of procollagen mRNA. Nucleic Acids Res 12: 2569-2579. [Crossref]

28. Murad S, Grove D, Lindberg KA, Reynolds G, Sivarajah A, et al. (1981) Regulation of collagen synthesis by ascorbic acid. Proc Natl Acad Sci U SA 78: 2879-2882. [Crossref]

29. Levy TE (2012). Primal Panacea. MedFox Publishing.

30. Harakeh S, Diab-Assaf M, Khalife JC, Abu-el-Ardat KA, Baydoun E, et al. (2007) Ascorbic acid induces apoptosis in adult T-cell leukemia. Anticancer Res 27: 289-298. [Crossref]

31. Mastrangelo D, Massai L, Lo Coco F, Noguera NI, et al. (2015) Cytotoxic effects of high concentrations of sodium ascorbate on human myeloid cell lines. Ann Hematol 94: 1807-1816. [Crossref]
32. Cárcamo JM, Pedraza A, Bórquez-Ojeda O, Zhang B, Sanchez R, et al. (2004) Vitamin $\mathrm{C}$ is a kinase inhibitor: dehydroascorbic acid inhibits IkappaBalpha kinase beta. $\mathrm{Mol}$ Cell Biol 24: 6645-6652. [Crossref]

33. Bowie AG, O'Neill LA (2000) Vitamin C inhibits NF-kappa B activation by TNF via the activation of $\mathrm{p} 38$ mitogen-activated protein kinase. J Immunol 165: 7180-7188 [Crossref]

34. Pathi SS, Lei P, Sreevalsan S, Chadalapaka G, Jutooru I, et al. (2011) Pharmacologic doses of ascorbic acid repress specificity protein $(\mathrm{Sp})$ transcription factors and $\mathrm{Sp}$ regulated genes in colon cancer cells. Nutr Cancer 63: 1133-1142. [Crossref]

35. Kim JE, Jin DH, Lee SD, Hong SW, Shin JS, et al. (2008) Vitamin C inhibits p53induced replicative senescence through suppression of ROS production and p38 MAPK activity. Int J Mol Med 22: 651-655. [Crossref]

36. Raymond YC, Glenda CS, Meng LK (2015) Effects of High Doses of Vitamin C on Cancer Patients in Singapore: Nine Cases. Integr Cancer Ther. [Crossref]

37. Hoffer LJ, Robitaille L, Zakarian R, Melnychuk D4, Kavan P5, et al. (2015) Highdose intravenous vitamin $\mathrm{C}$ combined with cytotoxic chemotherapy in patients with advanced cancer: a phase I-II clinical trial. PLoS One 10: e0120228. [Crossref]

38. Yamaoka M, Maeda N, Nakamura S, Kashine S, Nakagawa Y, et al. (2012) A pilot investigation of visceral fat adiposity and gene expression profile in peripheral blood cells. PLoS One 7: e47377. [Crossref]

39. Yamaoka M, Maeda N, Nakamura S, Mori T, Inoue K, et al. (2013) Gene expression levels of S100 protein family in blood cells are associated with insulin resistance and inflammation (Peripheral blood S100 mRNAs and metabolic syndrome). Biochem Biophys Res Commun 433: 450-455. [Crossref]

40. Dicker D, Salook MA, Marcoviciu D, Djaldetti M, Bessler H (2013) Role of peripheral blood mononuclear cells in the predisposition of obese individuals to inflammation and infection. Obes Facts 6: 146-151. [Crossref]

41. Koshiishi I, Imanari T (1997) Measurement of ascorbate and dehydroascorbate contents in biological fluids. Anal Chem 69: 216-220. [Crossref]

42. Bakaev VV, Efremov AV, Tityaev II (1999) Low levels of dehydroascorbic acid in uraemic serum and the partial correction of dehydroascorbic acid deficiency by haemodialysis. Nephrol Dial Transplant 14: 1472-1474. [Crossref]

43. Prins JB, Niesler CU, Winterford CM, Bright NA, Siddle K, et al. (1997) Tumo necrosis factor-alpha induces apoptosis of human adipose cells. Diabetes 46: 19391944. [Crossref]

44. Mikirova N, Riordan N, Casciari J (2016) Modulation of Cytokines in Cancer Patients by Intravenous Ascorbate Therapy. Med Sci Monit 22: 14-25. [Crossref]

45. Mikirova N, Casciari J, Rogers A, Taylor P (2012) Effect of high-dose intravenous vitamin C on inflammation in cancer patients. J Transl Med 10: 189. [Crossref]

46. Kensler TW, Wakabayashi N, Biswal S (2007) Cell survival responses to environmental stresses via the Keap1-Nrf2-ARE pathway. Annu Rev Pharmacol Toxicol 47: 89-116. [Crossref]

47. Hoeijmakers JH (2009) DNA damage, aging, and cancer. $N$ Engl J Med 361: $1475-$ 1485. [Crossref]

48. Harper JW, Elledge SJ (2007) The DNA damage response: ten years after. Mol Cell 28 739-745. [Crossref]

49. Martín-Montalvo A, Villalba JM, Navas P, de Cabo R (2011) NRF, cancer and calorie restriction. Oncogene 30: 505-520. [Crossref]

50. Ingram DK, Cutler RG, Weindruch R, Renquist DM, Knapka JJ, et al. (1990) Dietary restriction and aging: the initiation of a primate study. $J$ Gerontol 45: B148-163. [Crossref]

51. Kwak MK, Wakabayashi N, Greenlaw JL, Yamamoto M, Kensler TW (2003) Antioxidants enhance mammalian proteasome expression through the Keap1-Nrf2 signaling pathway. Mol Cell Biol 23: 8786-8794. [Crossref]

52. Leonard MO, Kieran NE, Howell K, Burne MJ, Varadarajan R, et al. (2006) Reoxygenation-specific activation of the antioxidant transcription factor Nrf2 mediates cytoprotective gene expression in ischemia-reperfusion injury. FASEB J 20: 2624-2626. [Crossref]

53. Lee JM, Shih AY, Murphy TH, Johnson JA (2003) NF-E2-related factor-2 mediates neuroprotection against mitochondrial complex I inhibitors and increased concentrations of intracellular calcium in primary cortical neurons. J Biol Chem 278: 37948-37956. [Crossref]

54. Kraft AD, Johnson DA, Johnson JA (2004) Nuclear factor E2-related factor 2-dependent 
Mikirova N (2016) Intravenous high-dose ascorbic acid reduces the expression of inflammatory markers in peripheral mononuclear cells of subjects with metabolic syndrome

antioxidant response element activation by tert-butylhydroquinone and sulforaphane occurring preferentially in astrocytes conditions neurons against oxidative insult. $J$ Neurosci 24: 1101-1112. [Crossref]

55. Suh JH, Shenvi SV, Dixon BM, Liu H, Jaiswal AK, et al. (2004) Decline in transcriptional activity of Nrf2 causes age-related loss of glutathione synthesis, which is reversible with lipoic acid. Proc Natl Acad Sci U S A 101: 3381-3386. [Crossref]

56. Praticò D, Delanty N (2000) Oxidative injury in diseases of the central nervous system: focus on Alzheimer's disease. Am J Med 109: 577-585. [Crossref]

Copyright: $\mathbb{0} 2016$ Mikirova N. This is an open-access article distributed under the terms of the Creative Commons Attribution License, which permits unrestricted use, distribution, and reproduction in any medium, provided the original author and source are credited. 